\title{
The Growth Responses of Potato Crops (Solanum tuberosum L.) in various type of Rhizobacteria and Mycorrhiza
}

\author{
Riska Gusnia Putri ${ }^{1}$, Warnita ${ }^{2 *}$, Benni Satria ${ }^{3}$
}

Department of Agriculture, Andalas University, Padang, Indonesia

\begin{abstract}
Potato (Solanum tuberosum L.) is a plant prefetch queue of five seasonal vegetables that are much in demand in Indonesia. Potato needs tend to increase every year in line with population growth and development of the food processing industry are made from raw potatoes. In general, potato production in Indonesia is still relatively low and still do to meet their import requirements. But the government has always sought to boost the national potato production. One of the efforts to improve potato production with the use of Plant Growth Promoting Rhizobacteria (PGPR) and fungi Mycorrhizal Fungi (AMF). The use of microorganisms PGPR and Mycorrhizae naturally associated with plant roots and have the ability to improve plant growth. The purpose of this study is to obtain the best interaction between species rhizobacteria and mycorrhiza on the growth of potato plants. This study is a two-factor factorial experiment with three replications in a randomized block design. First factor is type rhizobacteria which are without rhizobacteria, RZ3.L2.1, RZ3.L2.2, RZ3.L2.5. The second factor is the type of mycorrhizal wich are Glamus mycorrhiza, mycorrhizal and mycorrhizal Acaulospora sclerocystis, Data were analyzed by analysis of variance and DNMRT 5\%. The results showed that the best treatment for the growth of the potato crop is rhizobakteria RZ3.L2.2 with mycorrhizal glamus.
\end{abstract}

Keywords_potatoes, rhizobacteria, arbuscular mycorrhizal fungi.

\section{INTRODUCTION}

Potato (Solanum tuberosum L.) is one of the vegetables that are in Indonesia. Potatoes contain carbohydrates and high nutrition. In Indonesia, potatoes can also be used as an alternative food in addition to rice $^{(1)}$. Chips also includes plants prefetch queue of five seasonal vegetables. Potatoes are widely cultivated in Indonesia consists of three types of color bulbs. Yellow bulbous potato-like Granola, Cipanas, Cosima, and Thung 151 C. bulbous white potatoes such as Diamant and Marita. Potatoes red bulbous like Desiree and Kondor.

Potato needs tend to increase every year in line with population growth and development of the food processing industry are made from raw potatoes. But the market demand can not be met in terms of both quantity and quality. In general, potato production in Indonesia is still relatively low at $1,164,738$ tons and Indonesia still imports of potatoes amounted to 10,452 tons worth US $\$$ 4.65 million $^{(2)}$. Low national potato production to meet demand is influenced by several things including which agricultural land is increasingly narrowed from year to year, pests and diseases and the use of pesticides and inorganic fertilizers were excessive.
One effort to address the problem is by the use of Plant Growth Promoting Rhizobacteria (PGPR) and fungi Mycorrhizal Fungi (AMF). The use of microorganisms naturally PGPR in association with plant roots and have the ability to improve plant growth is a biological control techniques that lately developed rapidly. The use of rhizobacteria as biological agents that stimulate plant growth and increase crop yields predicted it would be an interesting study that continues to grow in agriculture in the future ${ }^{(3)}$.

\section{MATERIALS AND METHODS}

Penelitian di Nagari Baruah Gunuang Kecamatan Bukit Research in Nagari District of Bukit Barisan Gunuang Baruah, District Fifty Cities with altitude \pm 1000 masl. The experiment was conducted from November 2019 -Februari in 2020 and preparation of bacterial isolates Mikrobiology indigenous conducted at the Laboratory, Faculty of Agriculture, University of Andalas Padang, Materials used are seed potatoes, isolates Rhizobakteri, FMA, water, paper labels, plastic samples, envelopes, manure, lime, fertilizers NPK, The experiment was arranged according to the design of 4 x 3 with two factors in a randomized block design (RBD) with three replications. The treatments were 
kind Rizobakteri (R) and the type of Mycorrhizal Fungi Fungi (M). Type Rizobakteri (R) provided consisted of four types:

(R0) Without Rhizobakteri

(R1) RZ3.L2.1

(R2) RZ3.L2.2

(R3) RZ3.L2.5

Dose Mycorrhiza Fungi Fungi (M) Multispora namely:

(MG) mycorrhizal glamus

(MA) mycorrhizal Acaulospora

(MS) mycorrhizal sclerocystis

Data were analyzed by analysis of variance, if the Ftreatment count is greater than F-table then continued with Duncan's New Multiple Range Test at 5\% level.

\section{RESULT AND DISCUSSION}

\section{Ability Test Gas Hydrogen Cyanide (HCN)}

Table 1 shows that there are eight treatment has the ability to produce a high $\mathrm{HCN}$ and 4 treatment resulted in a low $\mathrm{HCN}$.

Table 1. Effect of Mycorrhizal Fungi Fungi Rhizobakteri and against HCN Potato

\begin{tabular}{|c|c|c|c|}
\hline Rhizobakteria & mycorrhizal & Discoloration & $\mathrm{HCN}$ \\
\hline \multirow{6}{*}{$\begin{array}{l}\text { Tanpa } \\
\text { Rhizobakteri }\end{array}$} & Mikoriza & & \\
\hline & glamus & Orange & +++++ \\
\hline & Mikoriza & & \\
\hline & acaulospora & Orange & +++++ \\
\hline & Mikoriza & & \\
\hline & sclerocystis & Orange & ++++ \\
\hline \multirow{6}{*}{ RZ3. L2.1 } & Mikoriza & & \\
\hline & glamus & Brown & + \\
\hline & Mikoriza & & \\
\hline & acaulospora & Brown & + \\
\hline & Mikoriza & & \\
\hline & sclerocystis & Orange & ++++ \\
\hline \multirow{5}{*}{ RZ3. L2.2 } & Mikoriza & & \\
\hline & glamus & Orange & +++ \\
\hline & $\begin{array}{l}\text { Mikoriza } \\
\text { acaulospora }\end{array}$ & Orange & +++ \\
\hline & Mikoriza & & \\
\hline & sclerocystis & Orange & +++ \\
\hline \multirow{5}{*}{ RZ3. L2.5 } & Mikoriza & & \\
\hline & glamus & Brown & + \\
\hline & Mikoriza & & \\
\hline & acaulospora & Brown & + \\
\hline & $\begin{array}{l}\text { Mikoriza } \\
\text { sclerocystis }\end{array}$ & Orange & +++ \\
\hline
\end{tabular}

++++ and +++ = high $\mathrm{HCN},+=$ low $\mathrm{HCN}$

Table 1 also shows that the treatment has the ability to produce a high HCN will be orange and brown lower. The color change caused by bacteria of sodium cyanide
$(\mathrm{NaCN})$, which is a combined reaction of picric acid / $\mathrm{Na} 2 \mathrm{CO} 3$ with cyanide. $\mathrm{NaCN}$ formed through cyanide gas absorption by $\mathrm{NaOH}$ or $\mathrm{Na} 2 \mathrm{CO} 3$ through the reaction between sodium and ammonia that initially will be formed $\mathrm{NaNH} 2$ that will react with the carbon and will produce sodium cyanamide ( $\mathrm{Na} 2 \mathrm{NCN})$ and eventually will be formed $\mathrm{NaCN}$ which is one type of cyanide. This shows that the brighter the color, the higher the isolates caused more HCN content of sodium cyanide were joined by ammonia (4). The color differences can be seen in Figure 1.

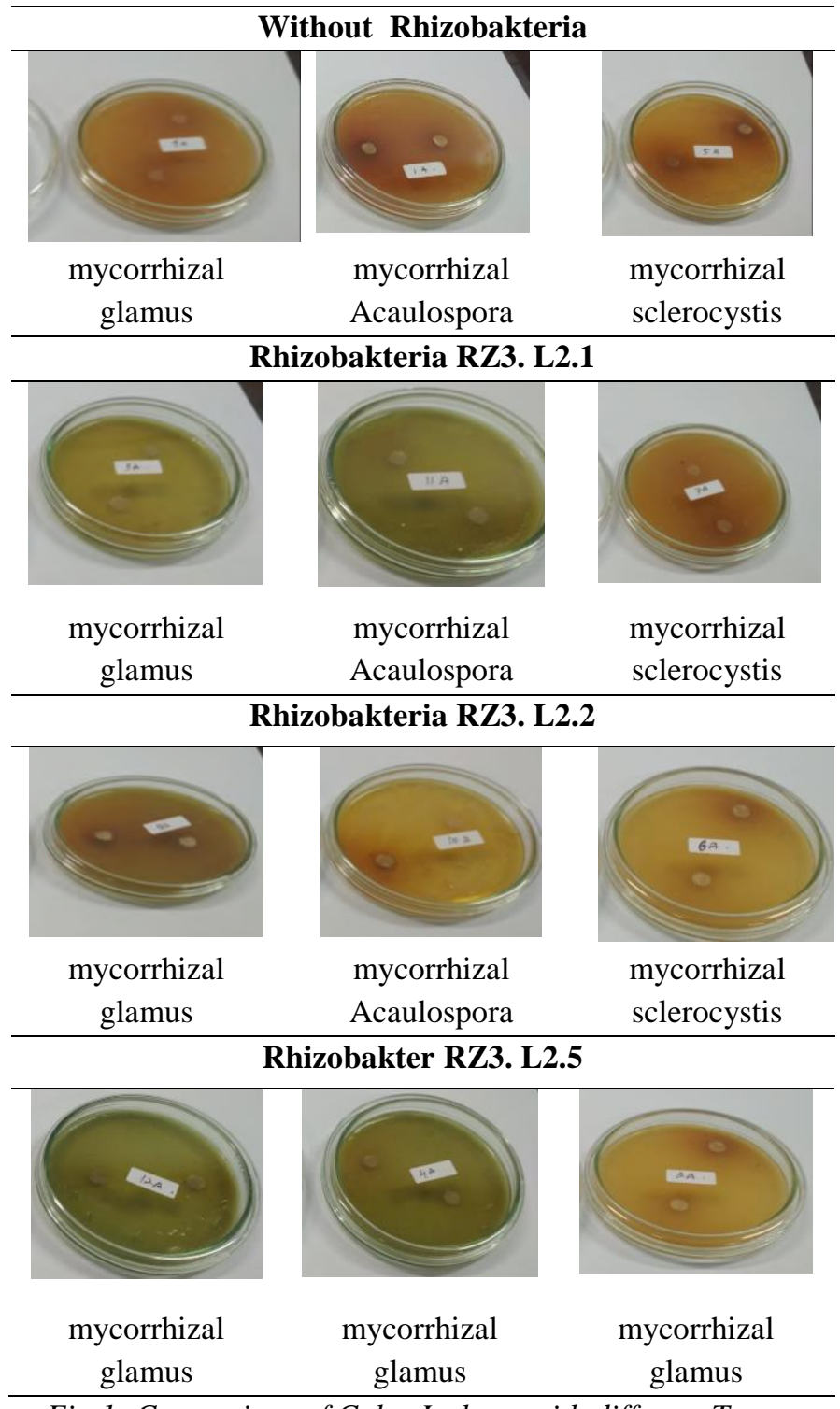

Fig. 1: Comparison of Color Isolates with different Types Rhizobakteria and Types Mycorrhizal

While connected to the potato crop, the presence of HCN gas in plant tissue produced by the endophytic bacteria act as a biocontrol environment of plants against weeds, diseases or nematodes. Rizobakteri mechanism as antagonists of pathogens carried by competition for nutrients $\mathrm{Fe}$ is also used for other microbial growth. But 
the existence of this $\mathrm{HCN}$ also appears to increase the growth of plant roots ${ }^{(5)}$.

Other studies have also suggested that the production of HCN one PGPR important properties, these compounds having biocontrol activity and can suppress pathogenic fungi on plant roots. It led to a better condition to root growth for microorganisms contained planting around the plant roots only beneficial microorganisms ${ }^{(6)}$.

\section{Infection percentage Roots}

Based on Table 2 can be seen that the plants are given rhizobacteria percentage of root infection were higher than without rhizobacteria. Rated highest percentage of root infection inRZ3.L2.2 followed RZ3.L2.5 and RZ3.L2.1. Table 2 also shows that Mycorrhizal glamus have highest percentage of root infection than Acaulospora mycorrhizal and mycorrhizal sclerocystis.

Table 2. Effect of Mycorrhizal Fungi Rhizobakteri and Infectious Fungi against Root Potato at Age 9 Week After Plant

\begin{tabular}{lcccc}
\hline \multirow{2}{*}{$\begin{array}{c}\text { Types } \\
\text { Rhizobakteria }\end{array}$} & \multicolumn{3}{c}{ Dosis FMA } & \\
\cline { 2 - 4 } & $\begin{array}{c}\text { mycorrhizal } \\
\text { glamus }\end{array}$ & $\begin{array}{c}\text { mycorrhizal } \\
\text { Acaulospora }\end{array}$ & $\begin{array}{c}\text { mycorrhizal } \\
\text { sclerocystis }\end{array}$ & \\
\hline Without & & & & \\
Rhizobakteria & 37,00 & 30,00 & 32,57 & $33,189 \mathrm{c}$ \\
RZ3.L2.1 & 67,33 & 34,47 & 52,23 & $51,344 \mathrm{~b}$ \\
RZ3.L2.2 & 67,77 & 61,10 & 56,67 & $61,844 \mathrm{a}$ \\
RZ3.L2.5 & 61,13 & 51,10 & 53,33 & $55,189 \mathrm{~b}$ \\
\hline Average & $58,308 \mathrm{~A}$ & $44,167 \mathrm{~B}$ & $48,700 \mathrm{~B}$ & \\
\hline KK = & $15,95 \%$ & & & \\
\hline
\end{tabular}

The figures followed the same lowercase letters in the same column and the same big letters on the same line by DNMRT no significant level of $5 \%$.

If adjusted to the classification of a root infection, then giving treatment rhizobacteria types or species of mycorrhizal root cause infections that are high and on the potato. Like wise, if compared with the Other research then the value of root infection acquired quite high because of infections acquired at the root of Jabon and sweet sorghum is $10 \%$. This condition is caused by a food reserve in Jabon and sweet sorghum is deposited on the rod so that the root exudates which may be used by esearhizobakteri less ${ }^{(6)}$.

Similar results were obtained in other studies, in which the highest root infection is obtained if the plant is given Glamus mycorrhizae. This may be due to the provision of RhizobakteriRZ3.L2.2 and Mycorrhizae glamus have a high $\mathrm{N}$ uptake than other treatments. $\mathrm{N}$ high nutrient uptake will increase the availability of food needed to increase the percentage of mycorrhizal root infection ${ }^{(7)}$.

Conformity with the requirements of research conditions to grow and proliferate rhizobacteria and FMA also an important requirement for root infection. Increasingly in accordance with the requirements of environmental conditions where the plants grow better plant growth and the higher the percentage of root exudates. Naturally around the plant roots already contains many microorganisms. The type and amount depends on the type of plant. Some types of microorganisms such as FMA have mutually beneficial relationships with plants. The plant is a provider of energy sources while microorganisms infect plant roots thereby increasing the availability of nutrients for plants. The higher the better root infection of plant growth. If the host plant can support the growth and proliferation of FMA well.

\section{IAA}

Table 3 shows that the plants are given rhizobacteria RZ3.L2.2 contains IAA with RZ3.L2.5 but unlike other treatments. Plants were given Mycorrhizae IAA glamus also contain higher than Acaulospora and Mycorrhizae Mycorrhizae sclerocystis.

Table 3. Effect of Mycorrhizal Fungi Fungi Rhizobakteri and against Total IAA Potato at Age 9 Week After Plant

\begin{tabular}{|c|c|c|c|c|}
\hline \multirow{2}{*}{$\begin{array}{c}\text { Types } \\
\text { Rhizobakteria }\end{array}$} & \multicolumn{3}{|c|}{ Dosis FMA } & \multirow[b]{2}{*}{ Average } \\
\hline & $\begin{array}{c}\text { mycorrhizal } \\
\text { glamus }\end{array}$ & $\begin{array}{l}\text { mycorrhizal } \\
\text { Acaulospora }\end{array}$ & $\begin{array}{l}\text { mycorrhizal } \\
\text { sclerocystis }\end{array}$ & \\
\hline \multirow{2}{*}{\multicolumn{5}{|c|}{ Without }} \\
\hline & & & & \\
\hline Rhizobakteria & 11,340 & 8,903 & 9,350 & $9,864 \mathrm{~b}$ \\
\hline RZ3.L2.1 & 10,797 & 9,627 & 10,007 & $10,143 \mathrm{~b}$ \\
\hline RZ3.L2.2 & 13,610 & 10,087 & 10,600 & $\begin{array}{l}11,432 \mathrm{a} \\
10,472\end{array}$ \\
\hline RZ3.L2.5 & 11,727 & 9,563 & 10,127 & $\mathrm{ab}$ \\
\hline Average & $11,868 \mathrm{~A}$ & $9,545 \mathrm{~B}$ & $10,021 \mathrm{~B}$ & \\
\hline $\mathrm{KK}=$ & $7,32 \%$ & & & \\
\hline
\end{tabular}

The figures followed the same lowercase letters in the same column and the same big letters on the same line by DNMRT no significant level of 5\%.

IAA value obtained in this study is quite high when compared to other studies. Other studies show that nine types of rhizobacteria only produce IAA less than $1 \mathrm{ug} / \mathrm{ml}$, 2 types rhizobacteria less than $1.5 \mathrm{ug} / \mathrm{ml}, 1$ kind rhizobacteria less than $3 \mathrm{ug} / \mathrm{ml}$ but one kind rhizobacteria $17.72 \mathrm{ug} / \mathrm{ml}$. While IAA obtained in this study is more evenly distributed in the range of grades $9 \mathrm{ug} / \mathrm{ml}$ to 11 $\mathrm{ug} / \mathrm{ml}$. This is due to rhizobacteria able to fix the roots well. IAA produced will be better when the plant has a root infection are high.

IAA production is influenced by many factors. The ability of endophytic bacteria in producing IAA isolates vary based on the type, age, culture, plants that become hosts and others. IAA synthesis by the microbial dependent pathway of tryptophan where tryptophan used as precursors and taxonomically diverse plant tissue and metabolic different. Some endophytic microorganisms have the potential to synthesize IAA to increase or 
stimulate the growth of the event with endophytic colonization $^{(6)}$.

Other research makes it clear that Capacity of rhizobacteria produce IAA is determined by the amount of the amino acid tryptophan provided root plants that can be synthesized by rhizobacteria. This is due to the amino acid tryptophan is a substrate for the formation of the IAA. The ability to produce IAA determined by the type rhizobacteria tested and the ability to colonize plant roots. Rizobakteri's ability to colonize plant roots has implications for the amount of the amino acid tryptophan derived from plant root exudates. IAA production by rhizobacteria will only happen if the concentration of the amino acid tryptophan in the root zone of plants is quite $\operatorname{high}^{(7)}$

One of the major contributions to the growth of these microorganisms plant is the production of molecules like auxin. 3 indole acetic acid (IAA) into the auxin can stimulate growth such as cell elongation and cell division and differentiation. Compounds Indole Acetic Acid (IAA) is a growth regulator substances classified in hormon and regulates the process of cell growth and development. IAA normally produced in microorganisms through the Ltryptophan. IAA produced by the bacteria around the roots acts as a carrier molecule communication signals between plants and microbes as well as supporting the growth of plants. IAA helps produce root becomes longer by increasing the number of root hairs and lateral roots are involved in decision-nutrition ${ }^{(9)}$.

\section{Indeks area index}

Table 4 shows that the leaf area index is proportional to the percentage of root infection. Potato plant leaf area index age 9 obtained at the highest MSTmycorrhizal glamus that is 0.499 , This may be dueMycorrhizal glamus have a better ability to root infection so that more optimal nutrient absorption and water which is needed in increasing the increase in the number and size of leaves. The treatment of many types of rhizobacteria apparently not affect the rate of assimilation of plants. However, rhizobacteria Award has a value higher net assimilation compared without giving rhizobakteria.
Table 4. Effect Rhizobakteri and fungi Mycorrhizal Fungi on Leaf Area Index Average Average Chips At Age 9 Week After Plant

\begin{tabular}{lcccc}
\hline \multirow{2}{*}{$\begin{array}{c}\text { Types } \\
\text { Rhizobakteria }\end{array}$} & $\begin{array}{c}\text { mycorrhizal } \\
\text { glamus }\end{array}$ & $\begin{array}{c}\text { mycorrhizl } \\
\text { Acaulospora }\end{array}$ & $\begin{array}{c}\text { mycorrhizal } \\
\text { sclerocystis }\end{array}$ & Average \\
\cline { 2 - 4 } Without & & 0,270 & 0,312 & $0,334 \mathrm{~b}$ \\
Rhizobacteria & 0,421 & 0,491 & 0,386 & $0,465 \mathrm{a}$ \\
RZ3.L2.1 & 0,516 & 0,350 & 0,473 & $0,449 \mathrm{a}$ \\
RZ3.L2.2 & 0,526 & 0,503 & 0,442 & $0,493 \mathrm{a}$ \\
RZ3.L2.5 & 0,533 & $0,403 \mathrm{~B}$ & $0,403 \mathrm{~B}$ & \\
\hline Average & $0,499 \mathrm{~A}$ & 0,4003 &
\end{tabular}

The figures followed the same lowercase letters in the same column and the same big letters on the same line by DNMRT no significant level of $5 \%$.

This indicates that the administration of rhizobacteria able to increase crop leaf area index. Although this type of rhizobacteria has its own characteristics, but the same leaf area index. Leaf area index value is closely related to the plant leaf area. Leaf area index is the ratio between leaf area and an area of land that is overgrown potato plants at any time. One of the factors that influence the value of the leaf area index is the number of leaves of the plant. Plants that have a large number also has a size that it leaves the plant will have a value of leaf area index is high ${ }^{(10)}$.

Increased leaf area index contributed positively to the growth of the plant because the leaf is the main organ where photosynthesis. However, the leaf area index value should not be too high and too low. Leaf area index is too high shows many leaves of the plant are inactive photosynthasis. This will inhibit the formation of tubers because the nutrients used by the organ that is not productive. However, the optimum number of leaves that allow the distribution of the light between the leaves evenly. Uniform light distribution across the leaves reduces the incidence of shade each other so that each leaf can cooperate as appropriate. Leaf area index at the beginning of the growth of most plants in the field is zero and for a few weeks and then can be below 1. 0 further increase in leaf area index ${ }^{(11)}$. Large leaf area is usually maintained until the close before maturity unless the leaves are affected by plant pests and the environment ${ }^{(12)}$.

\section{The rate of assimilation Net}

Table 5 shows that the potato plant without rhizobacteria with Mycorrhizal glamus had a net assimilation rate equal to the mycorrhizal sclerocystis but larger than Acaulospora mycorrhizae. Rhizobakteri RZ3.L2.1 with Mycorrhizae glamus have the same net assimilation rate with Acaulospora but with a different Mycorrhizae, Mycorrhizae Mycorrhizae Acaulospora sclerocystis but also together with Mycorrhiza sclerocystis. Rhizobakteri RZ3.L2.2 with Mycorrhizae glamus have the 
same net assimilation rate with sclerocystis Mycorrhizae Mycorrhizae but larger than Acaulospora. Rhizobakteri RZ3.L2.5 with Mycorrhizae glamus have the same net assimilation rate with sclerocystis Mycorrhizae Mycorrhizae but larger than Acaulospora. However, it can be concluded that all types of rhizobacteria have a high net assimilation rate if the Glamus mycorrhizae.

Table 5. Effect Rhizobakteri and Mycorrhizal Fungi against Net assimilation rate in the Potato Age 9 Week After Plant

\begin{tabular}{lccc}
\hline \multirow{2}{*}{$\begin{array}{c}\text { Types } \\
\text { Rhizobakteria }\end{array}$} & $\begin{array}{c}\text { Tycorrhizal } \\
\text { glamus }\end{array}$ & $\begin{array}{c}\text { mycorrhizl } \\
\text { Acaulospora }\end{array}$ & $\begin{array}{c}\text { mycorrhizal } \\
\text { sclerocystis }\end{array}$ \\
\cline { 2 - 4 } & \multicolumn{3}{c}{....mg per cm per week... $^{2}$} \\
\hline Without & $0,0071 \mathrm{a}$ & $0,0055 \mathrm{~b}$ & $0,0067 \mathrm{a}$ \\
Rhizobacteria & $\mathrm{A}$ & $\mathrm{A}$ & $\mathrm{A}$ \\
RZ3.L2.1 & $0,0092 \mathrm{a}$ & $0,0054 \mathrm{ab}$ & $0,0014 \mathrm{~b}$ \\
& $\mathrm{~A}$ & $\mathrm{~A}$ & $\mathrm{~B}$ \\
RZ3.L2.2 & $0,0062 \mathrm{a}$ & $0,0014 \mathrm{~b}$ & $0,0033 \mathrm{ab}$ \\
& $\mathrm{A}$ & $\mathrm{A}$ & $\mathrm{B}$ \\
RZ3.L2.5 & $0,0058 \mathrm{a}$ & $0,0016 \mathrm{~b}$ & $0,0051 \mathrm{a}$ \\
\hline KK & $\mathrm{A}$ & $\mathrm{A}$ & $\mathrm{A}$ \\
\hline
\end{tabular}

The figures followed the same small letters on the same line and the same capital letter in the same column according to DNMRT no significant level of $5 \%$.

Table 5 also shows that Mycorrhizae glamus and mycorrhizal Acaulospora have the same net assimilation rate even with or different types of rhizobacteria. However, Mycorrhizaesclerocystis with RZ3.L2.5 had net assimilation rate were as high as without rhizobacteria but larger than RZ3.L2.1 circuitry. But in general, the greatest assimilation rate obtained on mycorrhizal glamus with rhizobacteria RZ3.L2.1. This indicates that the plant has a value of root infection, leaf area index of the most well also have value net assimilation rate the highest.

The net assimilation rate is the average value of the photosynthetic efficiency of leaves that occur in plants cultivated potato. The highest net assimilation rate obtained when the plants are still small. This is due to the whole leaves of potato plants to get exposure to direct sunlight. Increasing the age of the plant assimilation rate, the value will also increase and the leaves are protected more cause impairment, net assimilation rate. Plants that have a high leaf area index had a chance to absorb the most sunlight, have the highest $\mathrm{CO} 2$ assimilation rate and tanslocationlargely the result of assimilation into other parts of the plants ${ }^{(13)}$.
The statement shows that the older the plant, the lower the value of the rate of assimilation of plants. Besides plants have leaf area index values that are too high will reduce the rate of assimilation value plants. The net assimilation rate also affects the reserves translocation of foods derived from metabolic processes ${ }^{(14)}$.

\section{CONCLUSION}

The best treatment of this research is rhizobacteria RZ3.L2.2 with mycorrhiza glamus against the net assimilation rate. Rhizobakteri RZ3.L2.2 and mycorrhizal glamus able to increase the value of $\mathrm{HCN}$, the percentage of root infection, IAA content, leaf area index and net assimilation rate.

\section{ACKNOWLEDGMENT}

This research was funded by the 'Batch Penelitian Tim Pascasarjana from the Ministry of Research, Technology and Higher Education of the Republic of Indonesia.

\section{REFERENCES}

[1] Gunadi, N. Karjadi, AK dan Sirajuddin. 2014. Pertumbuhan dan Hasil Beberapa Klon Kentang Unggul Asal Internasional Pottato Center Di Dataran Tinggi Malino Sulawesi Selatan. Balai Penelitian Tanaman Sayuran (BALITSA). Lembang.

[2] Badan Pusat Statistik (BPS) 2018 Data Produktivitas Kentang 2017.Badan Pusat Statistik. http://www.bps.go.id [02 Juni 2018].

[3] Sutariati G.A.K. dan Wahab, 2010.Perlakuan benih dengan agens biokontrol untuk pengendalian penyakit antraknosa dan peningkatan hasil serta mutu benih cabai. [Disertasi] Sekolah.

[4] Wandita, R. H., Pujiyanto, S., Suprihadi, A., \& Hastuti, R. D. Isolasi dan Karakterisasi Bakteri Endofit Pelarut Fosfat dan Penghasil Hidrogen Cyanide (HCN) dari Tanaman Bawang Merah (Allium cepa L). Bioma: Berkala Ilmiah Biologi, 20(1), 9-16.

[5] Aprillia, P., Zul, D., \& Fibriarti, B. L. (2014). Seleksi Kemampuan Bakteri Pelarut Fosfat Asal Bukit Batu-Riau dalam Menghasilkan Asam Sianida (Doctoral dissertation, Riau University).

[6] Agustiyani, D. (2017). Penapisan dan Karakterisasi Rhizobakteria serta Uji Aktivitasnya dalam Mendukung Perkecambahan dan Pertumbuhan Benih Jagung (Zea mays L.). Jurnal Biologi Indonesia, 12(2).

[7] Ilyas, S., \& Machmud, M. (2014). Karakterisasi rizobakteri yang berpotensi mengendalikan bakteri Xanthomonas oryzae pv. oryzae dan meningkatkan pertumbuhan tanaman padi. Jurnal Hama dan Penyakit Tumbuhan Tropika, 13(1), 42-51.

[8] Adelina, M,H. 2018. Pengaruh Pemberian Dosis Mikoriza terhadap Pertumbuhan Bibit Tanaman Jabon 
(Anthocephalus cadamba) pada Media yang Diberi Zat Allelopati. Skripsi. Universitas Sumatera Utara. $84 \mathrm{Hal}$.

[9] Gardner, F.P., R.B. Peace dan R.L. Mitchell. 1991. Fisiologi Tanaman Budidaya Universitas Indonesia Press 428. Jakarta.

[10] Indriani, N.P., Mansyur, Susilawati, I. danIslami, R.Z.2011. Peningkatan Produktivitas Tanaman Pakan melalui Pemberian Fungi Mikoriza Arbuskula (FMA).Pastura 1(1): $27-30$.

[11] Agustiyani, D. 2016. Penapisan dan Karakterisasi Rhizobakteria serta Uji Aktivitasnya dalam Perkembangan dan Pertumbuhan Benih Jagung (Zea mays L.). Jurnal Biologi Indonesia, 12(2). 241-248.

[12] Bhattacharyya, P. dan Jha, D. 2012. Plant Growth Promoting Rhizobacteria (PGPR) emergence in agriculture. World Journal of Microbiology and Biotecnology. 28. 1327-1350.

[13] Cahyani, C. Y, Nuraini. A, Gamal. 2018. Potensi Pemanfaatan Plant Growth Promoting Rhizobacteria (PGPR) dan Berbagai Media Tanam terhadap Populasi Mikroorganisme Tanah serta Pertumbuhan dan Produksi Kentang. J. Tan dan Sumber Daya Lahan. 5 (2). (887-899).

[14] Castro, S., Sowinski, Y., Okon, Y., and Jurkevitch, E. 2007. Ejects of inoculation with plant growth-promoting rhizobacteria on resident rhizosphere microorganisms. Universidad dela Republica, and Departamento de Bioqu' imica, Instituto Clemente Estable (IIBCE). 